\title{
New data on Callovian (Middle Jurassic) belemnites and palynomorphs from the Northern Caucasus, southwest Russia
}

\author{
Oksana S. Dzyuba ${ }^{1,}$, , Anna A. Goryacheva ${ }^{1}$, Dmitry A. Ruban ${ }^{2,3,}$, \\ Victoria V. Gnezdilova ${ }^{2}$, Pavel P. Zayats ${ }^{4}$ \\ ${ }^{1}$ Trofimuk Institute of Petroleum Geology and Geophysics, Siberian Branch of Russian Academy of Sciences, \\ Academician Koptyug Avenue 3, Novosibirsk 630090, Russia; \\ e-mail: dzyubaos@ipgg.sbras.ru, goryachevaaa@ipgg.sbras.ru \\ ${ }^{2}$ Department of Tourism, Higher School of Business, Southern Federal University, 23-ja linija Street 43, \\ Rostov-na-Donu 344019, Russia \\ ${ }^{3}$ postal address: P.O. Box 7333, Rostov-na-Donu 344056, Russia; e-mail: ruban-d@mail.ru \\ ${ }^{4}$ Camp for Practice and Educational Tourism 'Belaja Retchka', Southern Federal University, \\ Nikel' (Dakhovskaja Post Office), Majkop District, Republic of Adygeja 385792, Russia \\ *corresponding authors
}

\begin{abstract}
Palaeontological data on the Caucasus are highly important for large-scale stratigraphical and palaeobiogeographical assessment of the northern Tethyan margin, but this information is often scarce and not available in English. Field studies in the Northern Caucasus have now permitted to amass some new data. Two belemnite species are described from the stratotype section of the Kamennomostskaja Formation (Callovian, Middle Jurassic) near the town of Kamennomostskij in Adygeja (Northern Caucasus). These are Belemnopsis subhastata (von Zieten, 1831) and Rhopaloteuthis ominosa Gustomesov, 1968. The latter is a rare species, and the present find allows new insights into its taxonomy. A palynological analysis of the belemnite-bearing sample was carried out, and a diverse assemblage of dinocysts, acritarchs and prasinophytes, plus pollen and spores recognised. The most abundant palynomorphs are Micrhystridium and Classopollis. Data on belemnites coupled with those on palynomorphs indicate the early Callovian age of the sample level. This interpretation differs slightly from previous conclusions based on ammonites and dinocysts. If this age is correct, the degree of condensation of Callovian deposits in the section studied was lesser than previously assumed.
\end{abstract}

Keywords: macroinvertebrates, microfossils, condensed section, Mesozoic, Adygeja

\section{Introduction}

Stratigraphical and palaeobiogeographical reconstructions for the northern Tethyan margin during the Jurassic require palaeontological data on different fossil groups from many regions. One of the most important of those regions is the Caucasus which occupied a prominent position along this margin between the Eurasian platforms in the north and numerous terranes in the south (Stampfli \& Borel, 2002; Golonka, 2004; Ruban, 2006, 2007a;
Seton et al., 2012) and belonged to the Mediterran-Caucasian Subrealm/Province (Westermann, 2000). Although a plethora of palaeontological data have been accumulated for this region (Rostovtsev et al., 1992), some fossil groups remain insufficiently studied. These include Callovian belemnites and palynomorphs from the western part of the Northern Caucasus. The former were reviewed briefly by Krimholz (in Rostovtsev et al., 1992), and the latter were considered by Gaetani et al. (2005). Those preliminary overviews also stressed the importance of 
these groups for regional/interregional stratigraphical correlations. Belemnites and palynomorphs may be particularly useful with regard to the existing puzzle of ammonite-based dating of Callovian strata in the Northern Caucasus. Although an early-middle Callovian date is widely accepted, some finds and interpretations have implied slightly different ages (even Bathonian) of those deposits (Lominadze, 1982; Rostovtsev et al., 1992; Gaetani et al., 2005; Mitta, 2011).

Field work in the Northern Caucasus in July 2014 were aimed at belemnite sampling in the stratotype section of the Kamennomostskaja Formation (lower-middle Callovian, Middle Jurassic) near the town of Kamennomostskij (Majkop District, southern Republic of Adygeja, southwestern Russia; see Fig. 1). These works were preceded by investigations of the same section conducted since 1997 (e.g., Ruban, 2004, 2007b). The main target of the present paper is to provide descriptions and illustrations of the newly collected fossils. More generally, palaeontological data on the Caucasus were rarely published in any language other than Russian, and this gap should be filled in order to make the record of this region accessible to the above-mentioned stratigraphical and palaeobiogeographical studies concerning the development of the northern Tethyan margin during the Jurassic.

\section{Geological setting}

In the Middle Jurassic, the Caucasus was an active tectonic domain located to the south of the Russian Platform; island arcs and elongated sea basins existed there (Ershov et al., 2003; Ruban, 2006; Saintot et al., 2006; Adamia et al., 2011; Nikishin et al., 2012). Callovian deposits are distributed locally in the Northern Caucasus, and their age is established with ammonites and brachiopods (Rostovtsev et al., 1992). Lower-middle Callovian deposits are chiefly siliciclastic with a total thickness up to $600 \mathrm{~m}$; these overlie unconformably the older Mesozoic (Triassic and Jurassic) sedimentary rocks (Rostovtsev et al., 1992; Ruban, 2007b). Upper Callovian strata are basal layers of the thick Upper Jurassic carbonate platform succession, and these are separated from the lower-middle Callovian deposits by erosional surface (Rostovtsev et al., 1992; Ruban, 2012; Kiselev et al., 2013).

The Kamennomostskaja Formation comprises the lower-middle Callovian deposits in the Laba area of the western part of the Northern Caucasus (Rostovtsev et al., 1992). Its stratotype section is a natural outcrop in the steep left slope of the
Khadzhokh Canyon of the Belaja River near the town of Kamennomostskij (Fig. 1). Conglomerates, sandstones and shales of shallow-marine origin with abundant faunal remains (ammonites, belemnites, bivalves, brachiopods and echinoids), large plant remains, and trace fossils are present in this section; the total thickness of these deposits is $\sim 7$ m (Lominadze, 1982; Rostovtsev et al., 1992; Ruban, 2004, 2007a, b; Gnezdilova \& Ruban, 2014). Some characteristic features of condensed sections (Heim, 1934; Loutit et al., 1988; Gómez \& Fernández-López, 1994; Collin et al., 2005; Catuneanu, 2006; Zorina et al., 2009; Scarponi et al., 2013) are evident there (Gnezdilova \& Ruban, 2014). These include concentrations of fossils of different age in very thin layers (not a result of reworking), presence of glauconite, etc. The condensation appears to be local because the formation is much thicker in some other areas.

\section{Material and methods}

Belemnite remains are common in the section studied, although identifiable pieces are rare. Four belemnite rostra that allow taxonomic identification were collected from the studied section. Although some were found loose, all belemnites can be attributed to the same sandstone layer (Fig. 1). All illustrated Caucasian specimens are stored in the Central Siberian Geological Museum (CSGM) in Novosibirsk (Russia). The specimens were carefully examined, measured and identified (by O.S. Dzyuba). Belemnite terminology follows Doyle \& Kelly (1988) and Mariotti (2003). Abbreviations in the descriptions follow Doyle \& Kelly (1988): L, total preserved length; I, length from apex to tip of alveolus; Dv, dorso-ventral diameter at the tip of the alveolus; $\mathrm{Dl}$, lateral diameter at the tip of the alveolus; $\mathrm{Dv}_{\max }$ maximum dorso-ventral diameter; $\mathrm{Dl}_{\text {max }}{ }^{\prime}$ maximum lateral diameter; $X$, length from apex to $\mathrm{Dv}_{\max }$. Rostra were coated with magnesium oxide prior to photography.

Micropalaeontological investigation of the sandstone sample with fragments of belemnite rostra was attempted in order to assure stratigraphic control. In such a strongly condensed succession as represented in the studied section (Gnezdilova \& Ruban, 2014), even closely located layers may significantly differ in age. That is why age determination based on belemnites and microfossils from the same (!) sample provides valuable matter for further thoughts. The sample was proceeded by a standard procedure (cleaning with hydrochloric and hydrofluoric acids, pyrophosphate treatment, and separation of organic and mineral components 

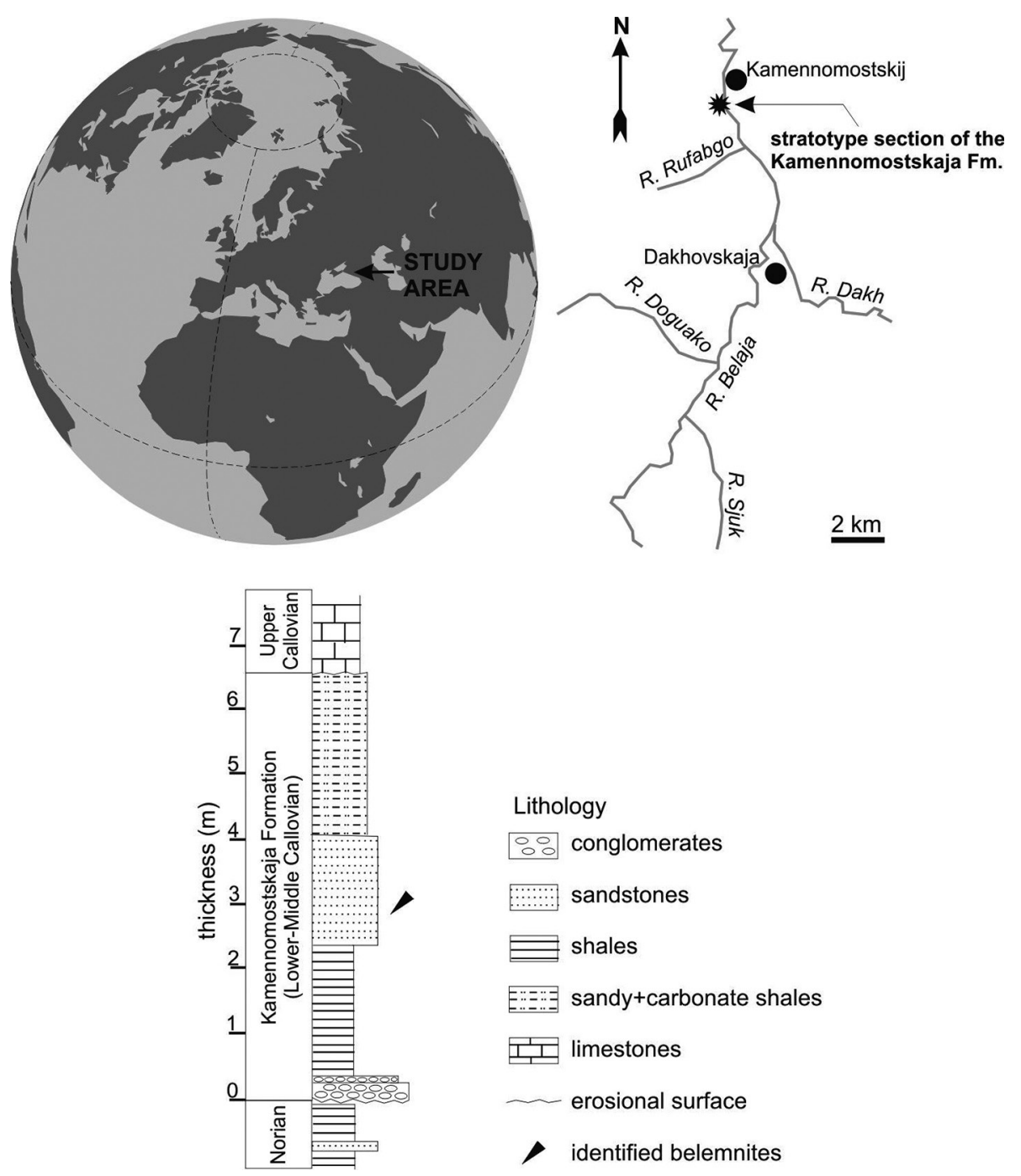

Fig. 1. Geographical location and stratigraphical framework (adapted from Ruban, 2007b) of the section studied. in heavy Cd liquid on centrifuge). After initial preparation, the palynological objects were examined with a Zeiss Primo Star microscope, the images were obtained with Zeiss Axioskop 40 and Canon PowerShot G10. The attempted analysis permitted to find diverse palynomorphs, including marine microphytoplankton and pollen and spores of terrestrial plants. For statistical treatment of palynological spectra and their interpretation, no fewer than 200 grains were counted.

\section{Palaeontological description of belemnites}

Subclass Coleoidea Bather, 1888

Order Belemnitida von Zittel, 1895

Suborder Belemnopseina Jeletzky, 1965

Family Belemnopseidae Naef, 1922 (emend. Jeletzky, 1946)
Genus Belemnopsis Bayle, 1878 (emend. Mitchell, 2015)

Belemnopsis subhastata (von Zieten, 1831)

(Figure 2A-E; Table 1)

*1831 Belemnites subhastatus von Zieten, p. 27, pl. 21, fig. 2.

pars 1848 Belemnites canaliculatus Schlotheim. -

Quenstedt, p. 436, pl. 29, figs 1-3, 5.

1869 Belemnites aripistillum Llwyd. - Phillips, p. 107, pl. 26, fig. 64.

non 1875 Belemnites subhastatus Zieten. - Waagen,

p. 14, pl. 2, fig. 1 [= Belemnopsis persulcata

Stolley, 1929; fide Riegraf, 1980].

1920 Hibolites subhastatus Zieten. - Bülow-

Trummer, p. 154.

1925 Belemnopsis subhastatus Zieten. - Lissajous, p. 141. 1931 Hibolites semihastatus Blainville. - Krimholz, p. 30, pl. 2, figs 1-3.

1934 Hibolites subhastatus Zieten. - Stoll, p. 36, pl. 3, fig. 11. 
1961 Belemnopsis subhastatus (Zieten). -

Pugaczewska, p. 154, text-fig. 15, pl. 12, fig. 2, pl. 13, figs $1-7$.

cf. 1969 Belemnopsis subhastatus (Zieten). - Galácz \& Vörös, p. 124, pl. 2, fig. 1.

1980 Belemnopsis (Belemnopsis) subhastata subhastata

(Zieten). - Riegraf, p. 195, pl. 3, fig. 25, text-fig. 182. 1980 Belemnopsis (Belemnopsis) subhastata informis. Riegraf, p.197, pl. 3, fig. 26, text-fig. 183.

1993 Belemnopsis subhastatus (Zieten). - Stoyanova-

Vergilova, p. 84, pl. 45, fig. 7.

1997 Belemnopsis fusiformis (Parkinson). -

Combémorel, 1. 28, fig. 2.

1998 Belemnopsis subhastata (Zieten). -

Schlegelmilch, p. 81, pl. 18, figs 1, 2.

2002 Hibolites semihastatus (Blainville). -

Topchishvili et al., p. 62, pl. 5, fig. 1.

cf. 2015 Hibolithes sp. - Gavrilov et al., p 1. 23, fig. 12. 2015 Hibolithes cf. longus (Stoyanova-Vergilova). -

Gavrilov et al., pl. 23, fig. 13.

Material. One juvenile specimen lacking the alveolar region (CSGM 2069/1), one juvenile specimen showing partially the stem and apical regions (CSGM 2069/2), and one juvenile specimen showing the apical region (CSGM 2069/3).

Description. The small-sized and elongate rostrum, with a flattened venter. The outline is slightly hastate with $\mathrm{Dl}_{\max }$ located slightly posterior of midpoint. The profile is symmetrical and cylindrical. The apex is acute. The cross section is depressed in the stem and apical regions. A ventral alveolar groove extends to the posterior stem region or even apical region where it broadens and fades out. Two lateral lines are weakly developed in the anterior part of the rostrum.

Remarks. Firstly, the characteristic slightly hastate outline and cylindrical profile, as well as the depressed cross section and the long ventral groove permit systematic attribution to juvenile forms of Belemnopsis subhastata. That species most closely resembles B. bessina (d'Orbigny, 1842), but the latter has a more conical profile. Hibolithes fusiformis (Parkinson, 1811) is also similar, but much more hastate. Secondly, from the Callovian of the Dakhovskaja section, which is situated $8-10 \mathrm{~km}$ to the south of the Kamennomostskij section, Krimholz (1931) recorded one specimen each of Hibolites semihastatus

Table 1. Dimensions (in $\mathrm{mm}$ ) for Belemnopsis subhastata (von Zieten, 1831).

\begin{tabular}{cccccccc}
\hline № & $\mathrm{L}$ & $\mathrm{l}$ & $\mathrm{Dv}$ & $\mathrm{Dl}$ & $\mathrm{Dv}_{\max }$ & $\mathrm{Dl}_{\max }$ & $\mathrm{X}$ \\
\hline CSGM 2069/1 & 51.7 & 51.7 & 4.2 & 4.9 & 5.0 & 6.2 & 24.5 \\
CSGM 2069/2 & 39.5 & - & - & - & 6.2 & 7.3 & - \\
\hline
\end{tabular}

(de Blainville, 1827) and H. cf. latesulcatus (Voltz in d'Orbigny, 1845). Neither of these specimens were illustrated. Belemnites latesulcatus Voltz in d'Orbigny, 1845 is now treated as primary homonym of Belemnites latesulcatus Voltz in Thurmann, 1832 (Riegraf et al., 1998; Mariotti et al., 2013) and even as a junior subjective synonym of Hibolithes semihastatus (Riegraf et al., 1998). Hibolithes semihastatus sensu Krimholz (1931) most likely belongs to Belemnopsis subhastata judging from a specimen from the Callovian of Chegem, Kabarda-Balkaria, Northern Caucasus (Krimholz, 1931, pl. 2, figs 1-3). This specimen is characterised by subcylindrical profile and long incised ventral groove. Hibolites semihastatus from the Callovian of western Georgia (Topchishvili et al., 2002, pl. 5, fig. 1), as well as Hibolithes sp. and Hibolithes cf. longus from the lower Callovian (Sigaloceras calloviense ammonite Zone, S. enodatum Subzone) of Dagestan, Northern Caucasus (Ippolitov in Gavrilov et al., 2015, pl. 23, figs 12-13) are considered here as Belemnopsis subhastata as well.

Occurrence. Bathonian of England and France; Bathonian to lowermost lower Callovian (Zigzag Zone to Macrocephalus Zone) of Germany; Bathonian-Callovian of Poland; Callovian of Hungary, the Crimean Peninsula (?), Kabarda-Balkaria and western Georgia; lower Callovian of Bulgaria (together with Macrocephalites) and Dagestan (Sigaloceras calloviense Zone). In Adygeja, the specimens are found in the Kamennomostskaja Formation, and the precise age of the layers is discussed below.

Family Duvaliidae Pavlow, 1914

Genus Rhopaloteuthis Lissajous, 1915

Rhopaloteuthis ominosa Gustomesov, 1968

(Figure 2F-I; Table 2)

?1931 Hibolites Gillieroni Mayer. - Krimholz, p. 33, pl. 2, figs 10-11 (non figs 12-14 = Rhopaloteuthis longa (Barskov \& Weiss, 1994)).

*1968 Rhopaloteuthis ominosus Gustomesov. -

Gustomesov \& Uspenskaya, p. 75, pl. 2, figs 3, ?4. 2005 Rhopaloteuthis gillieroni [Mayer]. - Shafeizad \& Seyed-Emami, pl. 12, fig. 11.

Material. A single specimen (CSGM 2069/4).

Description. The small-sized and stout rostrum shows a symmetrical and hastate outline and an asymmetrical and hastate profile. $\mathrm{Dl}_{\max }$ is located at one-third of the length from the apex. The apical region is short with a moderately obtuse, dorsally

Table 2. Dimensions (in $\mathrm{mm}$ ) for Rhopaloteuthis ominosa Gustomesov, 1968.

\begin{tabular}{cccccccc}
\hline № & $\mathrm{L}$ & 1 & $\mathrm{Dv}$ & $\mathrm{Dl}$ & $\mathrm{Dv}_{\max }$ & $\mathrm{Dl}_{\max }$ & $\mathrm{X}$ \\
CSGM 2069/4 & 51.0 & 40.0 & 6.2 & 9.0 & 10.5 & 12.0 & 15.0
\end{tabular}




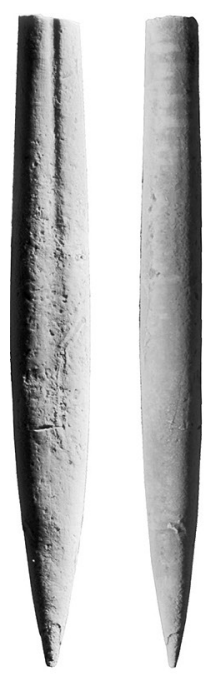

A

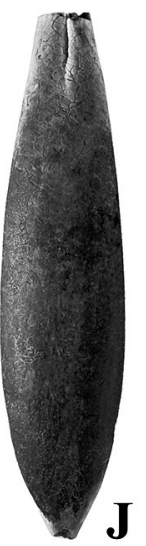

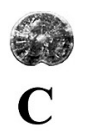

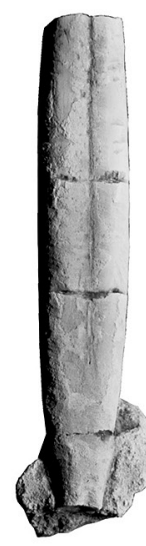

D

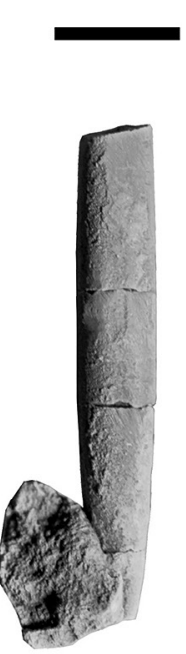

E

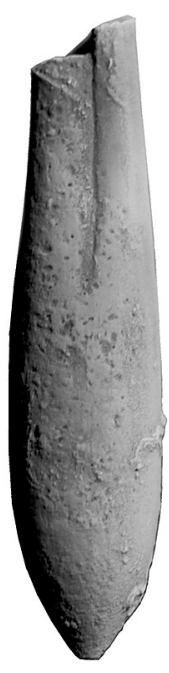

F

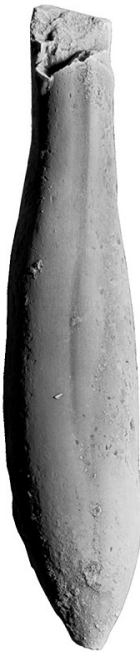

G

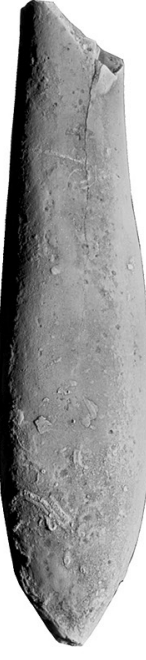

H

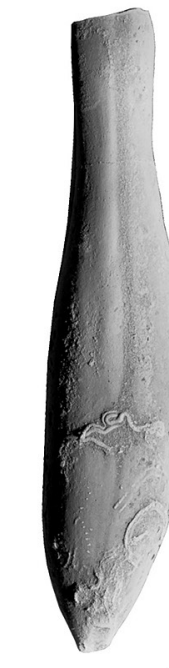

I

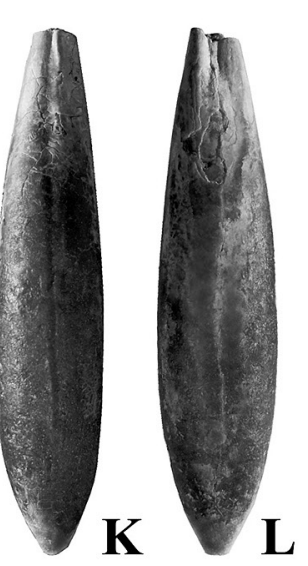

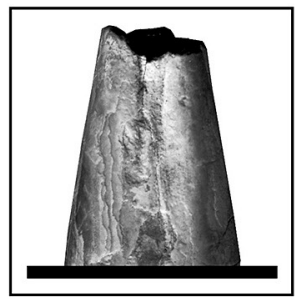

M

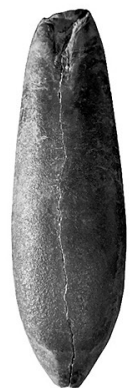

N

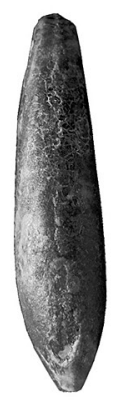

O

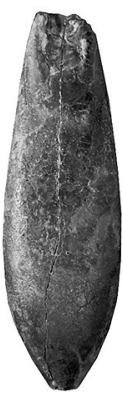

P

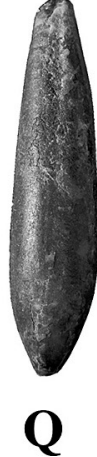

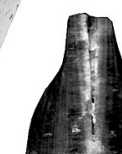
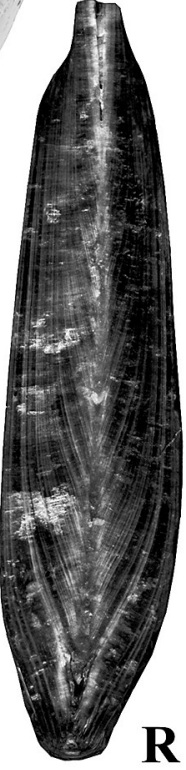

Fig. 2. Belemnites from the Kamennomostskaja Formation of the Northern Caucasus (A-I) and the type series of Rhopaloteuthis ominosa Gustomesov, 1968 (J-R). The latter includes specimens from the lower Callovian of Bogatoe Ushchel'e (Rich Canyon), Crimean Peninsula. All specimens (except where noted otherwise) are illustrated at natural size. Scale bar equals 10 mm. CSGM: Central Siberian Geological Museum (Novosibirsk); SGM RAS: Vernadsky State Geological Museum of the Russian Academy of Sciences (Moscow).

A-E - Belemnopsis subhastata (von Zieten, 1831); A-C - CSGM 2069/1, in ventral and right lateral views, and cross section at anterior end, respectively; D-E - CSGM 2069/2, in ventral and right lateral view, respectively; F-R Rhopaloteuthis ominosa Gustomesov, 1968; F-I - CSGM 2069/4, dorsal, left lateral, ventral view and right lateral views, respectively; J-M - paratype, SGM RAS VI-157/12, dorsal, left lateral, ventral views and fragment of anterior part in ventral view (×2), respectively; N-R - holotype, SGM RAS VI-157/11, in dorsal, left lateral, ventral, right lateral views and longitudinal section $(\times 2)$, respectively.

eccentric apex. The cross section is elliptical and strongly depressed, especially in the alveolar region. The dorsal alveolar groove, without alveolar slit area, extends up to the beginning of the stem region. Ventroalveolar flattening is present. Well-defined double lateral lines occur on flanks, diverging anteriorly.

Remarks. The present specimen most closely resembles the holotype of Rhopaloteuthis ominosa (see Gustomesov \& Uspenskaya, 1968, pl. 2, fig. 3; refigured here: Fig. 2N-R), but represents an adult individual of this species with better-preserved alveolar region. This species is distinguished from congeners by a remarkable ventroalveolar flattening, which was described by Gustomesov (in Gustomesov \& Uspenskaya, 1968, p. 75) as, "short and broad ventral groove". Later, $R$. ominosa was selected as type species (by original designation) of the monospecific genus Crimobelus Gustomesov, 1977, which is characterised by a dorsal alveolar groove in combination with a ventral alveolar groove. No other species of this genus are known to date. Actually, the so-called "ventral groove" of the holotype of $R$. ominosa resembles a more flattened depression 
which is slightly corroded owing to the poor preservation of the anterior part of the rostrum (Fig. 2P). Therefore, the generic names Rhopaloteuthis Lissajous, 1915 and Crimobelus Gustomesov, 1977 are treated here as synonyms. The illusion of a ventral groove is stronger in the paratype of R. ominosa (see Gustomesov \& Uspenskaya, 1968, pl. 2, fig. 4; reillustrated here: Fig. 2J-M), but the surface layers in the anterior part of this specimen show considerable damage (Fig. 2M). This specimen, as well as the other Crimean belemnite Hibolites gillieroni (Krimholz, 1931, pl. 2, figs 10-11) show transitional morphological characters between $R$. ominosa and R. gillieroni (Mayer, 1866).

Judging from the holotype, the earliest juvenile stage of R. ominosa is conical; subsequent stages resemble adult individuals. The apical line is slightly cyrtolineate to almost certainly ortholineate (Fig. 2R). Rhopaloteuthis ominosa is stouter than R. gillieroni and has a more asymmetrical profile and less straight lateral lines. It differs from $R$. sauvanausa (d'Orbigny, 1842) and R. bzoviensis (Zeuschner, $1869)$ by a strongly depressed cross section. A stout rostrum of $R$. gillieroni from the lower Callovian of Iran (Shafeizad \& Seyed-Emami, 2005, pl. 12, fig. 11) most likely belongs to R. ominosa.

Occurrence. Lower, and possibly upper, Callovian of the Crimean Peninsula and lower Callovian of Iran. In Adygeja, the specimen is found in the Kamennomostskaja Formation, and the precise age of the layers is discussed below.

\section{Discussion}

Belemnopsis subhastata is widely distributed in Europe, where it commonly is indicative of Bathonian to lower Callovian strata; this species was included by Combémorel (1997) in characteristic fauna of the western European Duvalia disputabilis belemnite Zone (Bathonian) and the Dicoelites meyrati Subzone (lower Callovian) of the Callovian Rhopaloteuthis gillieroni belemnite Zone. In the Caucasus, Belemnopsis subhastata appears for the first time in the Callovian, taking into account records from western Georgia (Topchishvili et al., 2002, as "Hibolites semihastatus"), Kabarda-Balkaria (Krimholz, 1931, as "Hibolites semihastatus"), Dagestan (Ippolitov in Gavrilov et al., 2015, as "Hibolithes sp." and "Hibolithes cf. longus") and Adygeja (the present paper). The Callovian species Rhopaloteuthis ominosa has been previously recorded only from the Crimean Peninsula (Gustomesov \& Uspenskaya, 1968). Here, we present the first record of this belemnite from the Northern Caucasus. The early Callovian specimen of $R$. gillieroni from Iran (Shafeizad \& Seyed-Emami, 2005) can be also attributed to $R$. ominosa. According to Gustomesov \& Uspenskaya (1968), five Crimean specimens of $R$. ominosa were collected from the lower Callovian, whereas two specimens were found in the upper Callovian, possibly due to reworking of lowermost Callovian deposits. In the Kamennomostskij section, Belemnopsis subhastata and Rhopaloteuthis ominosa, being found together, most likely represent elements of the early Callovian belemnite fauna.

Rhopaloteuthis and Belemnopsis are typical forms of the Mediterranean Tethys. Late Middle Jurassic representatives of Belemnopsis were also recorded from South America and the southwest Pacific (Challinor et al., 1992; Doyle et al., 1996; Doyle \& Pirrie, 1999), and the both genera are known from East Africa (Stevens, 1973; Combemorel, 1988) and West Antarctica (Doyle et al., 1996; Challinor \& Hikuroa, 2007). This way, the belemnite finds in the Kamennomostskij section contribute to the palaeontological characteristics of the Mediterran-Caucasian domain.

The palynological data from the sample with Belemnopsis subhastata (Fig. 3) have yielded interesting insights. Dinocysts are represented by Adnatosphaeridium caullery (Deflandre, 1939) Williams and Downie ( (3 specimens), Chytroeisphaeridia hyalina (Raynaud, 1978) Lentin and Williams, 1981 (1 specimen), Sentusidinium spp. (3 specimens), Dichadogonyaulax sellwoodii Sarjeant, 1975 (2 specimens), Ctenidodinium spp. (3 specimens), Pareodinia ceratophora Deflandre, 1947 (2 specimens), Pareodinia sp.

Fig. 3. (right) Palynomorphs from the Kamennomostskaja Formation of the Northern Caucasus.

A - Adnatosphaeridium caullery (Deflandre, 1939) Williams and Downie, scale bar $=20 \mu \mathrm{m}$; B - Sciadopityspollenites macroverrucosus (Thiergart, 1949) Iljina, 1985, scale bar $=20 \mu \mathrm{m} ; \mathrm{C}-$ Ctenidodinium sp., scale bar $=20 \mu \mathrm{m} ; \mathrm{D}-$ Gonyaulacysta jurassica (Deflandre, 1939) Norris and Sarjeant, 1965, scale bar $=20 \mu \mathrm{m}$; E - Tasmanites sp., scale bar $=50 \mu \mathrm{m}$; F, O - Micrhystridium sp., scale bar $=20 \mu \mathrm{m} ; \mathrm{G}, \mathbf{M}-$ Classopollis classoides (Pflug, 1953) Pocock and Jansonius, 1961, scale bar $=20 \mu \mathrm{m} ; \mathbf{H}$ - Vitreisporites pallidus (Reissinger, 1939) Nilsson, 1958, scale bar = $10 \mu \mathrm{m} ; \mathbf{I}-$ Cyathidites minor Couper, 1953, scale bar $=20 \mu \mathrm{m} ; \mathrm{J}-$ Classopollis torosus (Reissinger, 1950) Couper, 1958, scale bar $=20 \mu \mathrm{m} ; \mathrm{K}-\mathrm{Kluk}$ isporites variegatus Couper, 1958, scale bar $=20 \mu \mathrm{m} ; \mathrm{L}-$ Duplexisporites anagrammensis (Kara-Murza et Bolchovitina, 1956) Schugaevskaja, 1969, scale bar $=20 \mu \mathrm{m} ; \mathbf{N}$ - Perinopollenites elatoides Couper, 1958, scale bar $=20 \mu \mathrm{m} ; \mathbf{P}-$ Leiosphaeridia sp., scale bar $=20 \mu \mathrm{m}$. 

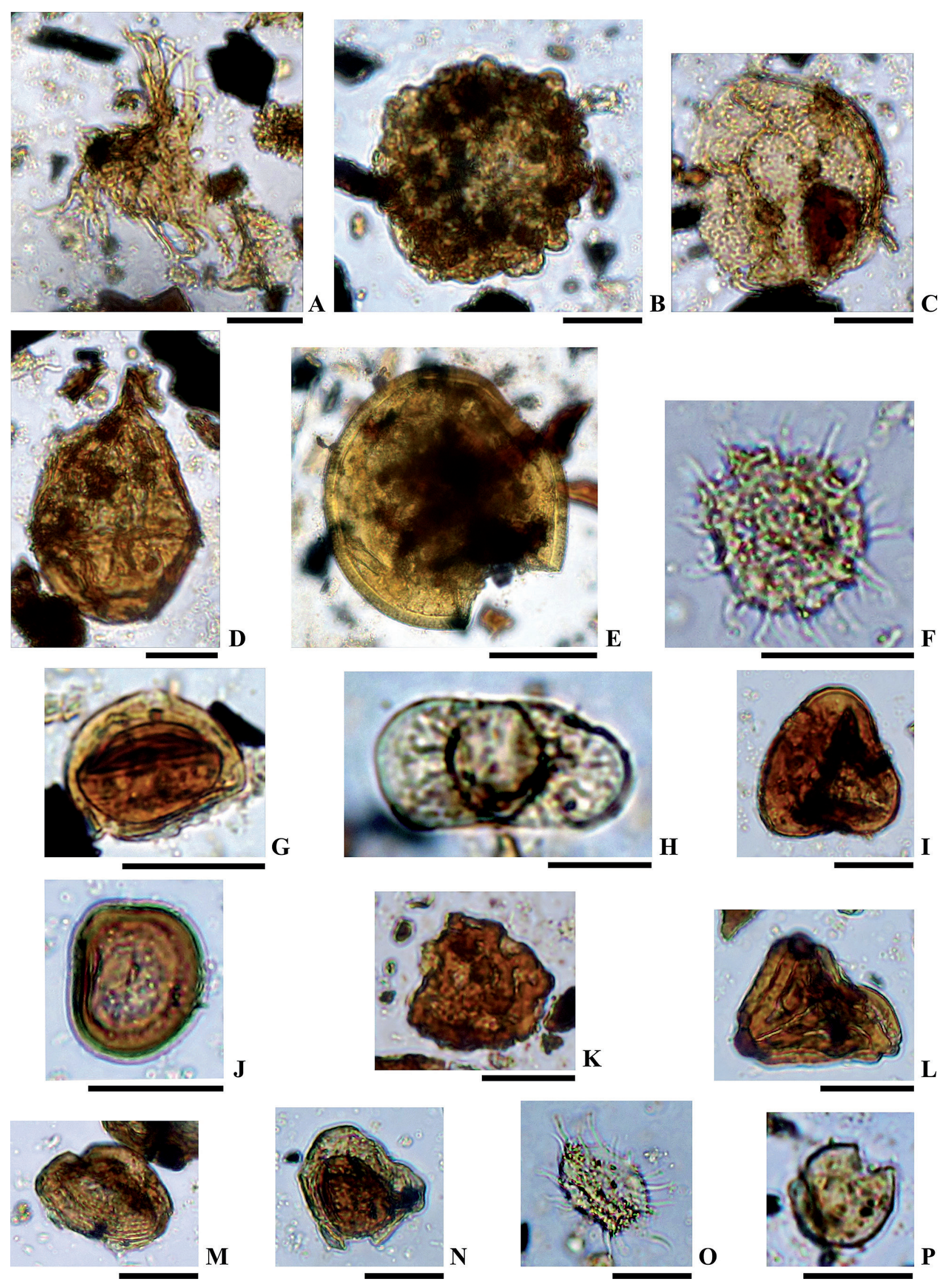
(3 specimens), Gonyaulacysta jurassica (Deflandre, 1939) Norris and Sarjeant, 1965 (1 specimen), Gonyaulacysta sp. (4 specimens) and Fromea sp. (1 specimen). Despite the small number and limited diversity of dinocysts, it should be noted that the first appearance of D. sellwoodii, C. hyalina, F. sp., and $P$. ceratophora in the Bathonian, G. jurassica near the Bathonian/Callovian boundary and A. caullery in the lower Callovian, as well as the last appearance of $D$. sellwoodi in the middle middle Callovian (Riding et al., 1999) imply together that the sample can be dated as early-middle Callovian. Acritarchs in the same sample are represented by Micrhystridium (45 specimens), Polygonium sp. (3 specimens) and Veryhachium sp. (1 specimen) and prasinophytes by Tasmanites sp. (2 specimens), Cymatiosphaera sp. (3 specimens) and Leiosphaeridia sp. (7 specimens). The occurrence of these microfossils implies accumulation of these deposits under open-marine conditions (see Strother, 1996), which is in agreement with a previous interpretation of the condensed section (Gnezdilova \& Ruban, 2014). Finally, pollen and spores have been found in the same section. The spore-pollen spectrum is dominated by gymnosperm pollen (146 specimens). Generally, pollen is represented by Classopollis (112 specimens), Ginkgocycadophytus sp. (8 specimens), Perinopollenites elatoides Couper, 1958 (7 specimens), Vitreisporites pallidus (Reissinger) Nilsson, 1958 (4 specimens), Sciadopityspollenites macroverrucosus (Thiergart, 1949) Iljina, 1985 (4 specimens), Caliallasporites dampieri (Balme, 1957) Dev, 1961 (4 specimens), Caliallasporites trilobatus (Balme) Dev, 1961 (2 specimens), Cycadopites sp. (2 specimens) and Araucariacites sp. (1 specimen). Spores include Cyathidites minor Couper, 1953 (11 specimens), Gleicheniidites sp. (4 specimens), Klukisporites variegatus Couper, 1958 (2 specimens), Cyathidites australis Couper, 1953 (2 specimens), Pilasporites marcidus Balme, 1957 (2 specimens), Densoisporites sp. (1 specimen), Lophotriletes sp. (1 specimen) and Duplexisporites anagrammensis (Kara-Murza et Bolchovitina, 1956) Schugaevskaja, 1969 (1 specimen). More or less similar palynological assemblages have been documented from the lower Callovian of the southern Russian Platform and vicinity (Besnosov et al., 1973; Vakhrameev, 1988; Panova et al., 1990; Yakovleva, 1993; Mitta et al., 2012).

Taken together, the new data on belemnites and palynomorphs imply an early Callovian age of the sandstone layer (Fig. 1) of the Kamennomostskaja Formation in its stratotype section. This conclusion corresponds only partially to the previous observation of the mixed early-middle Callovian ammonite assemblage from this level (Rostovtsev et al., 1992).
However, further revision of ammonites may lead to re-consideration of the age established on the basis of these fossils, as this was recently shown by Mitta (2011) for the section in another part of the Northern Caucasus. On the basis of dinocysts, Gaetani et al. (2005) suggested the age of the Kamennomostskaja Formation to be latest Bathonian to earliest Callovian. The new data presented here do not provide evidence of a Bathonian age of the sandstones. If the studied sandstone layer accumulated during the early Callovian (as well as three underlying layers), this entails a lower degree of local condensation of the entire sedimentary succession represented in the stratotype section of the Kamennomostskaja Formation. Earlier interpretations of strong condensation were based on the assumption that the entire siliciclastic succession was early-middle Callovian in age (Ruban, 2004). The exclusively early Callovian age indicates accumulation within a shorter time span (see www.stratigraphy.org for an updated geological time scale), i.e., a higher accumulation rate.

The significance of the palaeontological finds described in the present paper is also linked to the great value of geological heritage and, consequently, to the notable potential for geoconservation and geotourism of the stratotype section of the Kamennomostskaja Formation (Ruban \& Pugatchev, 2008; Gnezdilova \& Ruban, 2014). Detailed knowledge of fossil remains allows to manage their conservation efficiently and to regulate collecting by both specialists and occasional visitors.

\section{Conclusions}

Palaeontological examination of the stratotype section of the Kamennomostskaja Formation has permitted to document two belemnite species $(B e-$ lemnopsis subhastata and Rhopaloteuthis ominosa) and to revise their taxonomy, to characterise the palynological assemblage from the belemnite-bearing sample, which is of importance for this strongly condensed sedimentary succession and, finally, to draw conclusions on the early Callovian age of the deposits studied. It should be stressed that $R$. omniosa is a rare belemnite species; the new find from the Northern Caucasus improves our knowledge of this taxon. The generic name Crimobelus Gustomesov, 1977 (type: Rhopaloteuthis ominosus Gustomesov, 1968, by original designation) is treated here as a junior subjective synonym of Rhopaloteuthis Lissajous, 1915. These new finds improve our understanding of the Mediterran-Caucasian fauna. 


\section{Acknowledgements}

This paper is a contribution to the Russian Foundation for Basic Research project 13-05-00423 (A.A.G.). We thank R. Weis (Luxembourg) and an anonymous reviewer for valuable suggestions, D.N. Gar'kusha, O.V. Ivlieva, and many other past/present colleagues and students from the Southern Federal University (Russia) for field assistance, G.I. Skripka (Russia), who introduced the section studied to D.A.R. in 1997, I.L. Soroka (Russia), who provided photographs of specimens stored in the Vernadsky State Geological Museum of the Russian Academy of Sciences and S. Jain (India), N.M.M. Janssen (Netherlands), W. Riegraf (Germany), P. Tchoumatchenco (Bulgaria), A. Vörös (Hungary) and some other specialists for help with items of literature. This study would not have been possible without the earlier enthusiastic support from A.A. Baykov, M. Bécaud and V.I. Pugatchev - this paper is dedicated to their memory.

\section{References}

Adamia, S., Alania, V., Chabukiani, A., Kutelia, Z. \& Sadradze, N., 2011. Great Caucasus (Cavcasioni): A Long-lived North-Tethyan Back-Arc Basin. Turkish Journal of Earth Sciences 20, 611-628.

Bather, F.A., 1888. Shell growth in Cephalopoda (Siphonopoda). Annals and Magazine of Natural History 6, 298-310.

Bayle, E., 1878. Fossiles principaux des terrains de la France. Atlas. [In:] E. Bayle \& R. Zeiller (Eds): Explication de la carte géologique de France. 4, 1. Paris (Imprimerie Nationale), 176 pls.

Barskov, I.S. \& Weiss, A.F., 1994. The ontogeny and systematics of the Callovian-Oxfordian belemnites Produvalia and Pachyduvalia from the Crimea. Paleontological Journal 28, 81-96.

Besnosov, N.V., Burshtar, M.S., Vakhrameev, V.A., Krimholz, G.Ya., Kutuzova, V.V., Rostovtsev, K.O. \& Snegireva, O.V. (Eds), 1973. Ob"yasnitel'naya zapiska $k$ stratigraficheskoi skheme yurskikh otlozhenii Severnogo Kavkaza [Explanatory note on the stratigraphical schema of the Jurassic deposits of the Northern Caucasus]. Moscow (Nedra), 194 pp. (in Russian)

de Blainville, M.H.D., 1827. Mémoire sur les bélemnites, considérées zoologiquement et géologiquement. Strasbourg (Levrault), 136 pp.

Bülow-Trummer, E., 1920. Fossilium Catalogus. 1. Animalia, Pars 11, Cephalopoda dibranchiata. Berlin (Junk), 313 pp.

Catuneanu, O., 2006. Principles of sequence stratigraphy. Amsterdam (Elsevier), 375 pp.

Challinor, A.B. \& Hikuroa, D.C.H., 2007. New Middle and Upper Jurassic Belemnite Assemblages from West Antarctica (Latady Group, Ellsworth Land): Taxonomy and Paleobiogeography. Palaeontologia Electronica 10, 1-29.

Challinor, A.B., Doyle, P., Howlett, P.J. \& Nalnjaeva, T.I., 1992. Belemnites of the circum-Pacific region. [In:] Westermann, G.E.G. (Ed.): The Jurassic of the Cir-
cum-Pacific. New York (Cambridge University Press), 334-341.

Collin, P.Y., Loreau, J.P. \& Courville, P., 2005. Depositional environments and iron ooid formation in condensed sections (Callovian-Oxfordian, south-eastern Paris basin, France). Sedimentology 52, 969-985.

Combémorel, R., 1988. Les bélemnites de Madagascar. Documents des Laboratoires de Géologie Lyon 104, 1-239.

Combémorel, R., 1997. Bélemnites. Bulletin du Centre de Recherches Elf Exploration Production 17, 157-167.

Doyle, P. \& Kelly, S.R.A., 1988. The Jurassic and Cretaceous belemnites of Kong Karls Land, Svalbard. Skrifter Norsk Polarinstitutt 189, 1-77.

Doyle, P. \& Pirrie, D., 1999. Belemnite distribution patterns: implications of new data from Argentina. [In:] Olóriz, F. \& Rodríguez-Tovar, F.J. (Eds): Advancing research on living and fossil cephalopods. New York (Kluwer Academic), 419-436.

Doyle, P., Kelly, S.R.A., Pirrie, D., Riccardi, A.C. \& Olivero, E., 1996. Jurassic belemnite biogeography of the Southern Hemisphere: a comparative study from Antarctica and Argentina. Revista de la Associacion Geologica Argentina 51, 331-338.

Ershov, A.V., Brunet, M.-F., Nikishin, A.M., Bolotov, S.N., Nazarevich, B.P. \& Korotaev, M.V., 2003. Northern Caucasus basin: thermal history and synthesis of subsidence models. Sedimentary Geology 156, 95-118.

Gaetani, M., Garzanti, E., Poline, R., Kiricko, Yu., Korsakhov, S., Cirilli, S., Nicora, A., Rettori, R., Larghi, C. \& Bucefalo Palliani, R., 2005. Stratigraphic evidence for Cimmerian events in NW Caucasus (Russia). Bulletin de la Société géologique de France 176, 283-299.

Galácz, A. \& Vörös, A., 1969. Belemnite fauna of the ammonite-rich Callovian bed at Villány, South Hungary. Annales Universitatis Scientiarum Budapestinensis de Rolando Eötvös Nominatae, Sectio Geologica 12, 117-139.

Gavrilov, Yu.O., Zakharov, V.A., Rogov, M.A., Gulyaev, D.B., Ippolitov, A.P., Schepetova, E.V., Glinskikh, L.A. \& Desai, B., 2015. III.5. Tsudakhar. [In:] Cherkashin, V.I. (Ed.): Jurassic deposits of the central part of Mountain Dagestan. Field guide to the VI All-Russian conference "Jurassic system of Russia: problems of stratigraphy and paleogeography", September 15-20, 2015, Makhachkala. Makhachkala (ALEF), 81-105. (in Russian)

Gnezdilova, V.V. \& Ruban, D.A., 2014. Geotourism importance of condensed sections: a brief note. Natura Nascosta 48, 32-38.

Golonka, J., 2004. Plate tectonic evolution of the southern margin of Eurasia in the Mesozoic and Cenozoic. Tectonophysics 381, 235-273.

Gómez, J.J. \& Fernández-López, S., 1994. Condensation processes in shallow platforms. Sedimentary Geology 92, 147-159.

Gustomesov, V.A., 1977. K revizii yurskikh belemnitov [To revision of the Jurassic belemnites]. Byulleten' Moskovskogo Obshchestua Ispytatelei Prirody, otdel geologicheskii 2, 103-117. (in Russian)

Gustomesov, V.A. \& Uspenskaya, E.A., 1968. O rode Rhopaloteuthis (Belemnitidae) i ego krymskikh predstavitelyakh [On the genus Rhopaloteuthis (Belem- 
nitidae) and its Crimean representatives]. Bjulleten' Moskovskogo Obshchestva Ispytatelei Prirody, otdel geologicheskii 5, 65-78. (in Russian)

Heim, A., 1934. Stratigraphische Kondensation. Eclogae Geologicae Helvetiae 27, 372-383.

Jeletzky, J.A., 1946. Zur Kenntnis der oberkretazischen Belemniten. Geologiska Föreningens i Stockholm Förhandlingar 68, 87-105.

Jeletzky, J.A., 1965. Taxonomy and phylogeny of fossil Coleoidea (= Dibranchiata). Papers of the Geological Survey of Canada 65(2), 72-76.

Kiselev, D., Rogov, M., Glinskikh, L., Guzhikov, A., Pimenov, M., Mikhailov, A., Dzyuba, O., Matveev, A. \& Tesakova, E., 2013. Integrated stratigraphy of the reference sections for the Callovian-Oxfordian boundary in European Russia. Volumina Jurassica 11, 59-96.

Krimholz, G.Ya., 1931. Jurassic belemnites of the Crimea and Caucasus. Transactions of the Geological and Prospecting Service of U.S.S.R. 76, 1-52.

Lissajous, M., 1915. Quelques remarques sur les bélemnites jurassiques. Bulletin de la Société d'Histoire Naturelle de Mâcon 6, 1-32.

Lissajous, M., 1925. Répertoire alphabétique des Bélemnites jurassiques précédé d'un essai de classification. Travaux du Laboratoire de géologie de la Faculté des sciences de Lyon 8, 1-175.

Lominadze, T.A., 1982. Kelloveiskie ammonitidy Kavkaza [Callovian ammonitids of the Caucasus]. Tbilisi (Metsniereba), 300 pp. (in Russian)

Loutit, T.S., Hardenbol, J., Vail, P.R. \& Baun, G.R., 1988. Condensed sections: the key to age determination and correlation of continental margin sequences. [In:] Wilgus, C.K., Hastings, B.S., Kendall, C.G.St.C., Posamentier, H.W., Ross, C.A. \& Van Wagoner, J.C. (Eds): Sea-Level Changes - An Integrated Approach. Society for Economic Paleontologists and Mineralogists Special Publication 42, 39-45.

Mariotti, N., 2003. Systematics and taphonomy of an Early Kimmeridgian belemnite fauna from the Mediterranean Tethys (Monte Nerone, Central Apennines, Italy). Geobios 36, 603-623.

Mariotti, N., Weis R., Falahatgar, M., Parent, H. \& Javidan, M., 2013. Oxfordian belemnites and ammonites from Rostam Kola, Northern East Alborz, North Iran. Boletin del Instituto de Fisiografia y Geología 83, 15-26.

Mayer, K., 1866. Diagnoses de bélemnites nouvelles. Journal de Conchylogie 3, 358-369.

Mitchell, S., 2015. A reassessment of the validity and affinities of Belemnites sulcatus Miller, 1826, Belemnopsis Edwards in Gray, 1849, and Belemnopsis Bayle, 1878. Carnets de Géologie 15, 31-39.

Mitta, V.V., 2011. Ammonity pogranichnykh otlozhenii bat-kelloveya Severnogo Kavkaza [Ammonites from the Bathonian-Callovian boundary beds of the Northern Caucasus]. [In:] Shurygin, B.N., Lebedeva, N.K. \& Goryacheva, A.A. (Eds): Paleontologija, stratigrafija i paleogeografija mezozoja i kajnozoja boreal'nykh regionov, Novosibirsk (INGG SO RAN), 1: 184-187. (in Russian)

Mitta, V.V., Alekseev, A.S. \& Shik, S.M. (Eds.), 2012. Unifitsirovannaya regional'naya stratigraficheskaya skhema yurskikh otlozhenii Vostochno-Evropeiskoi platformy.
Ob"yasnitel'naya zapiska [Unified regional stratigraphic scheme of the Jurassic deposits of the East-European Platform. Explanatory note]. Moscow (PIN RAN, VNIGNI), 64 pp. (in Russian)

Naef, A., 1922. Die fossilen Tintenfische. Eine paläozoologische Monographie. Jena (G. Fischer), 322 pp.

Nikishin, A.M., Ziegler, P.A., Bolotov, S.N. \& Fokin, P.A., 2012. Late Palaeozoic to Cenozoic Evolution of the Black Sea-Southern Eastern Europe Region: A View from the Russian Platform. Turkish Journal of Earth Sciences 21, 571-634.

d'Orbigny, A.D., 1842-1851. Paléontologie française. Description des mollusques et rayonnés fossiles. Terrains oolithiques ou jurassiques. Vol. 1. Céphalopodes. Masson, Paris, 624 pp.

Panova, L.A., Oshurkova, M.V. \& Romanovskaya, G.M. (Eds), 1990. Prakticheskaya palinostratigrafiya [Practical palynostratigraphy]. Leningrad (Nedra), 348 pp. (in Russian)

Parkinson, J., 1811. Organic remains of a Former World. Vol. 3. London (Whittingham \& Rowland), $479 \mathrm{pp}$.

Pavlow, A.P., 1914. Yurskie i nizhnemelovye Cephalopoda Severnoi Sibiri [Jurassic and Lower Cretaceous Cephalopoda of Northern Siberia]. [In:] Résultats scientifiques de l'Expédition Polaire Russe en 1900-1903, sous la direction du Baron E. Toll. Sect. C. Géologie et paléontologie. Livr. 4. Mémoires de l'Académie Impériale des Sciences de St.-Pétersbourg. Série 8. Classe physico-mathématique 4, 1-68. (in Russian)

Phillips, J., 1869. The Belemnitidae. Part 4. Liassic and Oolitic Belemnites. Monograph of the Palaeontographical Society London 97, 89-108.

Pugaczewska, H., 1961. Belemnoids from the Jurassic of Poland. Acta Paleontologica Polonica 6, 105-236.

Quenstedt, F.A., 1848. Petrefactenkunde Deutschlands 1: Die Cephalopoden 4. Tübingen (Fues), 265-408.

Riding J.B., Fedorova V.A. \& Ilyina V.I., 1999. Jurassic and lowermost Cretaceous dinoflagellate cyst biostratigraphy of the Russian Platform and northern Siberia, Russia. American Association of Stratigraphic Palynologists Contributions Series 36, 1-179.

Riegraf, W., 1980. Revision der Belemniten des Schwäbischen Jura. Teil 7. Palaeontographica (Series A) 169, 128206.

Riegraf, W., Janssen, N.M.M. \& Schmitt-Riegraf, C., 1998. Cephalopoda dibranchiata fossiles (Coleoidea) II. [In:] Westphal, F. (Ed.): Fossilium Catalogus I: Animalia. Pars 135. Leiden (Backhuys Publishers), 1-512.

Rostovtsev, K.O., Agaev, V.B., Azarian, N.R., Babaev, R.G., Besnosov, N.V., Hassanov, N.A., Zesashvili, V.I., Lomize, M.G., Paitschadze, T.A., Panov, D.I., Prosorovskaya, E.L., Sakharov, A.S., Thodria, V.A., Topchishvili, M.V., Abdulkasumzade, M.R., Avanesian, A.S., Belenkova, V.S., Bendukidze, N.S., Vuks, V.Ya., Doludenko, M.P., Kiritchkova, A.I., Klikushin, V.G., Krimholz, G.Ya., Romanovskaya, G.M. \& Schevchenko, T.V., 1992. Yura Kavkaza [Jurassic of the Caucasus]. St. Petersburg (Nauka), 192 pp. (in Russian)

Ruban, D.A., 2004. Terrigennyi kellovei Severo-Zapadnogo Kavkaza [Terrigenous Callovian of the North-Western Caucasus]. Izvestiya VUZov. Seve- 
ro-Kavkazskii region. Estestvennye nauki 4, 85-86. (in Russian)

Ruban, D.A., 2006. The Palaeogeographic Outlines of the Caucasus in the Jurassic: The Caucasian Sea and the Neotethys Ocean. Geološki Anali Balkanskoga Poluostrva $67,1-11$.

Ruban, D.A., 2007a. Jurassic transgressions and regressions in the Caucasus (northern Neotethys Ocean) and their influences on the marine biodiversity. Palaeogeography, Palaeoclimatology, Palaeoecology 251, 422436.

Ruban, D.A., 2007b. Major Paleozoic-Mesozoic Unconformities in the Greater Caucasus and Their Tectonic Re-Interpretation: A Synthesis. GeoActa 6, 91-102.

Ruban, D.A., 2012. Erosional surface at the Middle-Upper Callovian (Middle Jurassic) transition in the Greater Caucasus Basin (northern Neo-Tethys) and tracing its presence in Western Europe, North Africa and Arabia: the influence of regional tectonics. Comunicações Geológicas 99, 69-76.

Ruban, D.A. \& Pugatchev, V.I., 2008. Khadzhokhskii kan'on i Granitnoe ushchel'e (Adygeja, Rossiya) kak geologicheskie pamyatniki prirody [The Khadzhokhsky canyon and the Granitnoye gorge (Adygeja, Russia) as geological natural monuments]. Geografiya i Prirodnye Resursy 1, 62-66. (in Russian)

Saintot, A., Brunet, M.-F., Yakovlev, F., Sébrier, M., Stephenson, R., Ershov, A., Chalot-Prat, F. \& McCann, T., 2006. The Mesozoic-Cenozoic tectonic evolution of the Greater Caucasus. [In:] Gee, D.G., Stephenson, R.A. (Eds): European Lithosphere Dynamics. Geological Society, London, Memoirs 32, 277-289.

Scarponi, D., Kaufman, D., Amorosi, A. \& Kowalewski, M., 2013. Sequence stratigraphy and the resolution of the fossil record. Geology 41, 239-242.

Seton, M., Müller, R.D., Zahirovic, S., Gaina, C., Torsvik, T., Shephard, G., Talsma, A., Gurnis, M., Turner, M., Maus, S. \& Chandler, M., 2012. Global continental and ocean basin reconstructions since $200 \mathrm{Ma}$. Earth-Science Reviews 113, 212-270.

Shafeizad, M. \& Seyed-Emami, K., 2005. Lithostratigraphy and biostratigraphy of the Dalichai Formation West of Shahroud (Eastern Alborz). Geosciences 14, 98-113.

Schlegelmilch, R., 1998. Die Belemniten des süddeutschen Jura. $1^{\text {st }}$ edit. Stuttgart (Fischer), 151 pp.

Stampfli, G.M. \& Borel, G.D., 2002. A plate tectonic model for the Paleozoic and Mesozoic constrained by dynamic plate boundaries and restored synthetic oceanic isochrons. Earth and Planetary Science Letters 196, 17-33.

Stevens, G.R., 1973. Jurassic belemnites. [In:] Hallam, A. (Ed.): Atlas of Palaeobiogeography. Amsterdam, 259274.
Stoll, E., 1934. Die Brachiopoden und Mollusken der pommerschen Doggergeschiebe. Abhandlungen aus dem Geologisch-Palaeontologischen Institut der Ernst-Moritz-Arndt-Universität Greifswald 13, 1-62.

Stoyanova-Vergilova, M., 1993. Yurska sistema: Belemnitida [Jurassic System: Belemnitida]. [In:] Fosilite na Bulgariya, 3a. Sofia (Bulgarskata Akademiya na Naukite), 212 pp. (in Bulgarian)

Strother, P.K., 1996. Acritarchs. [In:] Palynology: Principles and Applications. Principles. Vol. I. AASP Foundation, 81-106.

Thurmann, J., 1832. Essai sur les soulèvements jurassiques de Porrentruy. Mémoires du Muséum d'histoire naturelle de Strasbourg 1, 1-90.

Topchishvili, M.V., Keleptrishvili, Sh.G. \& Kvantaliani, I.V., 2002. Yurskie i melovye belemnitidy Gruzii [Jurassic and Cretaceous belemnitids of Georgia]. Georgian Academy of Sciences A.I. Djanelidze Geological Institute, Proceedings, New series 118, 1-301. (in Russian)

Vakhrameev, V.A., 1988. Yurskie $i$ melooye flory $i$ klimaty Zemli [Jurassic and Cretaceous floras and climates of the Earth]. Moscow (Nauka), 209 pp. (in Russian)

Waagen, W., 1875. Jurassic fauna of Kutch. Memoirs of the Geological Survey of India. Palaeontologia Indica 1, 1-106.

Westermann, G.E.G., 2000. Marine faunal realms of the Mesozoic: review and revision under the new guidelines for biogeographic classification and nomenclature. Palaeogeography, Palaeoclimatology, Palaeoecology 163, 49-68.

Yakovleva, S.P. (Ed.), 1993. Unifitsirovannaya stratigraficheskaya skhema yurskikh otlozhenii Russkoi platformy [Unified stratigraphic scheme of the Jurassic deposits of the Russian Platform]. St. Petersburg (VNIGRI), 72 pp. (in Russian)

Zeuschner, L., 1869. Uber Belemnites bzoviensis, eine neue Art aus dem untersten Oxfordien yon Bzow bei Kromolow. Zeitschrift der Deutschen Geologischen Gesellschaft 21, 565-568.

von Zieten, C.H., 1830-1833. Die Versteinerungen Wtirttembergs. Stuttgart, 102 pp.; H. 1-2: 1-16 [1830], H. 3-4: 17-32 [1831], H. 5-8: 33-64 [1832], H. 9-12: 65-102 [1833] (Expeditum des Werkes unserer Zeit).

von Zittel, K.A., 1895. Grundzüge der Palaeontologie (Palaeozoologie), 7. Oldenbourg, München \& Leipzig, 971 pp.

Zorina, S.O., Ruban, D.A. \& van Loon, A.J., 2009. A condensed succession at the Jurassic/Cretaceous transition in a shallowing basin on the eastern Russian Platform. Geološki Anali Balkanskoga Poluostrva 70, 1-8.

Manuscript submitted 18 March 2015 Revision accepted 26 November 2015 